\title{
Perceptions of Students and Teachers Toward Guidance and Counseling Services in South West Ethiopia Secondary Schools
}

\author{
Aminu Jibril Arfasa \\ Department of Psychology, College of Education and Behavioral Sciences, Jimma University, Ethiopia \\ Email: aminujibri145@yahoo.com
}

http://dx.doi.org/10.18415/ijmmu.v5i6.504

\begin{abstract}
The study was intended to examine practices of Perception of Teachers and Students for Guidance and Counseling services in South west Ethiopia Secondary Schools. The research design was a descriptive survey research. The total participants of study were 500 and among total participants 108 were teachers and 394 were students. The study was used Multi stage sampling techniques. At first stage among 78 secondary school in south west Ethiopia, 8 secondary schools were selected by random sampling techniques using lottery methods. On the second stage 392 students and 108 teachers were selected by systematic sampling techniques. The instruments of data collection was Likert scale closedended self- administered questionnaire used and validation of the instruments was done by using experts' review and discussion. The study was used quantitative methods of data analysis. The analysis of data was done using descriptive statistical measurements like, percentage, mean, standard division, and independent t-test were computed to analysis the response from students, and teachers. The results of study indicated that the students and teachers mean perception scores to needs of guidance and counseling for students learning was positive. The perceptions of both students and teachers to ward school guidance and counseling services working on students future career, personal problems and students empowerments and decision making was negative. The computed independent t-test result revealed that there was no statistical significant difference between students and teachers means perception scores guidance and counseling services which was implies both teachers and students had the same perception for services of guidance and counseling in their schools. The mean perception of the students toward the non trained individuals could be of guidance and counselor officers were average while perception teachers were negative. Regarding to cost effectiveness of guidance and counseling services both students and teacher's perception means score were negative. From these results it was recommended that Since perceptions of students and teachers may affected based on the guidance and counseling survives; Education bureau in collaboration with higher educational institutions should prepare on job training to improve counseling skills of the guidance and counselors officers.
\end{abstract}

Keywords: Guidance; Counseling; Perceptions; Secondary Schools 


\section{Introduction}

The importance of school-based collaboration where school personnel work together to address student development and learning goals. The school counselor is an integral part of this team (Dougherty., 2000). Studies on the effects of school counseling have shown positive results on student's grades, reducing classroom disruptions, and enhancing teachers' abilities to manage classroom behavior effectively. High-quality school counseling services can help to address students' mental health needs (U.S. Department of Education., 2002). It is believed that when school counselors have time, resources, and the better counseling room structure to work in, the counseling interventions programs improve students' academic achievement (Day., 2004).

Perceptions towards a phenomenon potentially influence its practice and success. Perception involves the identification and interpretation of information to understand an issue in the environment (Schacter., 2011). According to Mundia (1993), for an enhanced performance as a counselor, school environment, teacher counselor's qualification and availability of resources have a great role to play. For continued seeking for guidance and counseling services, counselors', principals', teachers' and students' perceptions towards counseling therefore count.

Counselors can offer expertise in many areas, including personal, social, academic, and career, which in turn can help teachers better understand their students' strengths and needs and foster student success (Beale., 2003). Also teachers have a large impact on students' uptake of school counseling services (Dougherty., 2000). Teachers' perceptions of the responsibilities and roles of the school counselor can influence the likelihood of them making referrals to school counselors, consulting with school counselors, and can even impact on the overall success of the student, as well as the school counseling program itself (Beale., 2003).

Perceptions of counselors and students may largely determine the practice and success of guidance and counseling at schools. There is an ongoing challenge towards the implementation of guidance and counseling, despite many well-acknowledged facts about its merits (Gladding., 2004). In the opinion of Gladding (2004), the perceptions and interpretations of teachers and students about guidance and counseling services are among the major challenges for effective practice and implementation. The perception of teachers and students to ward services of the guidance and counseling also influences the practice either positively or negatively.

Mwangi (2002) on studying student perception of guidance and counseling in Loreto secondary schools sought to determine whether students' perceptions of guidance and counseling programme was affected by teacher counselor' age, gender or level of training in counseling skills. His findings showed that students did not consider the age, sex or level of training of teacher counselors when seeking for guidance and counseling services. However, the number of students seeking for guidance and counseling was noted to be below average. Wachira (1997) carried out a study on the preparation of secondary school heads and implications on their performance and found out that lack of training in guidance and counseling contributed to incompetence of the teacher-counselor hence unfavorable attitude towards the program.

The perception of teachers and students is likely to be positive or negative depending on what the teachers and students feel and perceive about the whole issues of counseling. Shertzer and Stone, (1981) support that, guidance and counseling services underscore the fact that other people opinions and decisions may have positive impact on the guidance and counseling services program. In the context of a school, teachers and students are expected to have very diverse attitude and perception about a situation that requires the attention of both of them. However, a common ground has to be reached in order for something to be done especially when that thing involves collaboration of all parties of a transaction (UNESCO., 2011). 
Chireshe (2011: 103) was conducted study on School Counselors' and Students' Perceptions of the Benefits of School Guidance and Counseling Services in Zimbabwean Secondary Schools. His study results showed that academic achievement and secure school environment as benefits of guidance and counseling were negatively viewed by both school counselors and students. However, both school counselor and students were highly rated benefits of guidance and counseling included improved study habits, posiative self-image, reduced anxiety and efficient use of time. However, the more positive reactions in the stu $\neg$ dents' responses of the ratios of the different ben 7 efits were positive attitude, career exposure and improved class behavior.

Mutie and Ndambuki (1999) have noted that student' wrong perceptions towards guidance and counseling has led to the failure of the guidance and counseling program. This has in turn affected the education process. It is important to help students develop the right perceptions towards guidance and counseling as this will enable them seek for the services voluntarily. Yunis (2006) goes on to explain that the attitudes held by students towards seeking help also determines how effectively counseling resources are used. Therefore, students with positive attitudes towards seeking help are more likely to seek counseling than those with negative attitude. As such, special attention must be drawn to students' attitudes towards guidance and counseling services and counselors, so as to develop willingness to seek for these services.

Teachers and students have tremendous impact on school counselling service utilization in terms of teacher-counsellor consultation and student referral. Thus, ensuring that teachers and students understand the roles and responsibilities of school counsellors is critical. A number of studies indicated teachers do not always have a positive view of the role of the school psychologist or they view the position as less valuable than the school counsellor (Dean., 1980; Gilman \& Gabriel., 2004; Gilman \& Medway., 2007). When the school guidance and counselling services are not provided for effectively, both teachers and students develop perceptions which may hinder their continued seeking for the same (Comfort, 2013). A number of studies indicated teachers do not always have a positive view of the role of the school psychologist or they view the position as less valuable than the school counsellor (Dean, 1980; Gilman \& Gabriel., 2004; Gilman \& Medway., 2007).

Even if many researchers were conducted on practice and challenges of guidance and counselling in Ethiopia secondary schools; teachers' and students' perceptions of services of the school counselling not studied in Ethiopia. Therefore, the current study was interested to investigate perception of teachers and students toward services of guidance and counselling in south west Ethiopia secondary schools.

\section{Objectives of the Study General Objective of the Study}

The general objectives of the study was to investigate teachers and students perceptions of guidance and counselling services in south west Ethiopia secondary schools.

\section{Specific Objectives of the Study}

The study was guided by the following objectives:

1. To analyze teachers and students perceptions about guidance and counselling services in south west Ethiopia secondary school 
2. To analysis the relationship between teachers ${ }^{\text {ee }}$ and students ${ }^{\text {ee }}$ perceptions of counseling and guidance services in secondary schools in south west Ethiopia.

\section{Research Question}

The study was guided by the following research questions:

1. What are teachers and students perceptions about guidance and counselling services in south west Ethiopia secondary school?

2. What is the relationship between teachers ${ }^{\text {ee }}$ and studentse perceptions of counseling and guidance services in secondary schools in south west Ethiopia?

\section{Significance of the Study}

The findings of the research would help governmental and non-governmental organizations which are working on sustainability and improvement of guidance and counselling services at secondary schools. The result from the study would help in throwing more light on relevance of secondary school guidance and counselling services, how teachers and students are perceived their school guidance and counselling services.

\section{Scope of the Study}

The study was carried out in secondary schools in south west Ethiopia secondary schools, particularly in secondary schools located at in Jimma, Ilu Ababor, Kefa and Benchi Maji Zone. Responses from the selected schools can be used to represent responses for the whole south west Ethiopia secondary schools. The study focused on students' and teachers' perception of the needs for guidance and counselling services benefit, as well as types of services availability in selected secondary schools.

\section{Methodology Research Design}

A survey design, which was mainly quantita $\neg$ tive in nature, was used for this study. The sur $7 v e y$ design is usually appropriate where research $\neg$ ers seek the opinion of participants (David and Sutton., 2004) with the aim of describing the naרture of existing phenomenon (Cohen et al., 2000). The present study sought to establish the perาceived benefits and types of school guidance and counseling services. The study therefore, sought information from a sample of teachers and students all of whom had different backgrounds, training, age, and experiences. This was why the survey design was seen as more desirable.

\section{Study Area}

The study area was four zones (Benchi Maji, Kefa, Jimma and Iluabbbor zone) south west Ethiopia secondary schools. 


\section{Study Population}

There were 78 secondary schools in south west Ethiopia. Among the secondary schools in the study areas 8 secondary schools were selected. The study target populations were on secondary school teachers and students from 8 government schools in south west Ethiopia. All these brought the total population to 20,430 Prospective respondents which were; (14 teachers from each of the 8 schools and aroun 49 students from each of the 8 secondary schools in south west Ethiopia). From the population size, the sample size of 500 respondents was considered basing on a sampling by using Yamane (1967) simple calculation formula. The study populations were only government secondary schools, teachers, and students. Teachers were use because they are the ones who are engaged in referring students to guidance and counselling and were therefore, considered to their perception could positively or negatively affect provision of guidance and counselling services. The students were used because they are the recipients and beneficiary of the counselling services.

\section{Sample and Sampling Techniques}

The study would follow Multi stage sampling techniques. At First stage among 78 secondary school in south west Ethiopia, 8 secondary schools were selected by random sampling techniques using lottery methods. On the second stage among total 20,430 secondary school students 392 students were selected by systematic sampling techniques. Among total 430 teachers in the study area 108 teachers were selected random sampling techniques. Sample size of both teachers and students were calculated by using Yamane (1967) simple calculation formula as follow:

\section{Instruments of Data Collection}

In the current study, interviews and the Likert scale closed-ended self- administered questionnaire items were used.

\section{Questionnaires}

This instrument was developed in a way that it would maximize the possibility of generating answers to the basic research questions. There are kinds of self-report questionnaires focus on the leading question. The study used questionnaires which con $\neg$ sisted mainly of the Likert scale closed-ended selfadministered questionnaire items were used. Questionnaires are normally used in survey designs (Cohen et al., 2000). There was a questionnaire for the teachers and another one for the students. The reliability of the instruments was established through a test-re-test procedure with 15 teachers and 30 students. The results of the test-re-test scores showed a Pearson correlation of 0.85 for the teachers' questionnaire and 0.83 for the students' questionnaire reflect $\neg$ ing that the instruments was reliable.

\section{Data Collection Procedures}

The instruments were administered for selected teachers and students of south west Ethiopia secondary schools. During administration the participants were informed to read or follow the instruction carefully before responding to the items and they will made to fill out the questionnaire in addition , participants were requested to fill the questionnaire privately because response of one participant may influenced by others and to kept confidentiality of the respondents. 


\section{Data Analysis}

The current study was used both quantitative methods of data analysis. The analysis of data was done using descriptive statistical measurements like, percentage, mean, standard division, and independent t-test were computed to analysis the response from students, and teachers.

\section{Ethical Consideration}

The collection data from respondents was based on willingness. The participants were also informed that the information provided would only be used for the study purposes and that it would not be given to a third part.

\section{Result and Discussion}

The aim of the study was to investigate perception of teachers and students for guidance and counseling services in South west Ethiopia secondary schools. In the present chapter, the data generated from the current study participants presented and discussed in line with of the research question.

\section{Demographic Characteristics of the Research Participants}

Table 1 Demographic data of students research participants

\begin{tabular}{cccc}
\hline Secondary school students & No of schools & Number & Percentage \\
\hline Gender & Male & 240 & 61.2 \\
& Female & 152 & 38.8 \\
& Total & 392 & 100.0 \\
\hline Age & $13-15$ & 48 & 12.2 \\
& $16-18$ & 277 & 70.7 \\
& 19 and above & 67 & 17.1 \\
& Total & 392 & 100.0 \\
\hline Counseling usage & Seek & 155 & 39.5 \\
& Not seek & 237 & 60.5 \\
& Total & 392 & 100.0 \\
\hline Frequency of visit & None & 149 & 38.0 \\
& One time & 150 & 38.3 \\
& Two times & 92 & 23.5 \\
& Three times & 67 & 17.1 \\
& Four times & 36 & 9.2 \\
& Five and more times & 20 & 5.1 \\
& Total & 392 & 100.0 \\
\hline
\end{tabular}

Table 1 reveals that the total number of student were 392 which is $240(61.2 \%)$ of them were males and $152(38.8 \%)$ were females. The majority of the secondary school student participants were aged between 16 and 18 years and the minority of them were aged between 13 and 15 years. Among all students participants only $155(39.5 \%)$ seek for counseling services while the remaining $137(60.5 \%)$ did 
not visit the school guidance and counseling center. Among students who had visited counseling center $150(38.3 \%)$ visit only one time, $92(23.5 \%)$ twice and only $20(5.1 \%)$ had visited counseling center more than five times.

Table 2 Demographic data of teacher's participants

\begin{tabular}{llll}
\hline Teacher & & Number & Percent \\
\hline Gender & Male & 76 & 70.4 \\
& Female & 32 & 29.6 \\
& Total & 108 & 100.0 \\
\hline Age & $20-25$ & 21 & 19.4 \\
& $26-29$ & 29 & 26.9 \\
& $30-33$ & 38 & 35.2 \\
& $34-37$ & 10 & 9.3 \\
& $38-41$ & 5 & 4.6 \\
& 42 and above & 5 & 4.6 \\
& Total & 108 & 100.0 \\
\hline Educational level & Diploma & 4 & 3.7 \\
& First degree & 88 & 81.5 \\
& Masters degree & 15 & 13.9 \\
& Other & 1 & .9 \\
Total & 108 & 100.0 \\
\hline Total teaching experience & $1-5$ & 17 & 15.7 \\
& $6-10$ & 33 & 30.6 \\
& $11-15$ & 20 & 18.5 \\
& $16-20$ & 12 & 11.1 \\
& $21-25$ & 11 & 10.2 \\
& 26 and above & 15 & 13.9 \\
& Total & 108 & 100.0 \\
\hline
\end{tabular}

As showed in Table 2, among the 108 teacher respondents in the study, 76 (70.4\%) were males while the remaining $32(29.6 \%)$ were females. Regarding to the age of teachers participants, 21 (19.4\%) found age range of 20-25, 29 (26.9\%) found age range of 26-29, 38 (35.2\%) found age range of 30-33, 10 (9.3\%) age range between 34-37, 5(4.6\%) age range of 38-41 and $5(4.6 \%)$ found above 42 years old. The major age of teacher participants were between 30- 3329 (35\%), while few $5(4.6 \%)$ teachers were above 42 age. This indicated that majority of teachers participants were found at age range of 30-33. Majority of teachers participants $88(81.5 \%)$ were first degree holders, $15(13.9 \%)$ were secondary degree holders while $4(3.7 \%)$ were diploma holders. Among teachers participants $33(30.6 \%)$ of them have total experiences 6-10 years, 20 (18.5\%) 11-15 total years experience while $11(10.2 \%)$ have above 26 years experiences. 


\section{Perceptions of Students Toward Guidance and Counseling Services}

Table 3 Perceptions of students toward guidance and counseling services

\begin{tabular}{|c|c|c|c|c|c|c|c|}
\hline \multirow{2}{*}{ No } & \multirow[t]{2}{*}{ Statements } & \multicolumn{3}{|c|}{ Students } & \multicolumn{3}{|c|}{ Teachers } \\
\hline & & $\mathrm{N}$ & Mean & Std & $\mathrm{N}$ & Mean & Std \\
\hline 1. & $\begin{array}{l}\text { Whether guidance and counseling services } \\
\text { needed for students learning. }\end{array}$ & 392 & 3.40 & 1.24 & 108 & 4.10 & 1.04 \\
\hline 2 & $\begin{array}{l}\text { Whether guidance and counseling improves } \\
\text { student learning }\end{array}$ & 392 & 4.01 & 1.22 & 108 & 4.17 & 1.22 \\
\hline 3 & $\begin{array}{l}\text { Believe whether non trained individual can } \\
\text { give the survive of G\&C }\end{array}$ & 392 & 2.99 & 1.37 & 108 & 2.06 & .96 \\
\hline 4 & $\begin{array}{l}\text { Opinion whether a counselor should be } \\
\text { trained }\end{array}$ & 392 & 3.54 & 1.39 & 108 & 4.61 & .72 \\
\hline 5 & $\begin{array}{l}\text { Opinion whether counseling service is cost } \\
\text { effective }\end{array}$ & 392 & 2.90 & 1.38 & 108 & 2.96 & 1.62 \\
\hline 6 & $\begin{array}{l}\text { Guidance is being given based on need } \\
\text { assessment }\end{array}$ & 392 & 2.23 & 1.37 & 108 & 2.24 & 1.12 \\
\hline 7 & $\begin{array}{l}\text { Whether guidance is given for students on } \\
\text { future career, personal problems and } \\
\text { students empowerments and decision } \\
\text { making }\end{array}$ & 392 & 2.26 & 1.40 & 108 & 1.98 & 1.40 \\
\hline
\end{tabular}

Table 3 shows that the means perception rating of the students' and teachers' scores concerning need of guidance and counseling services were $(\mathrm{M}=3.4$ with $\mathrm{SD}=1.24)$ and $(\mathrm{M}=3.29$ with $\mathrm{SD}=1.28)$ respectively. The mean rating showed that both teachers and students were positive perception toward need of guidance and counseling in their schools. This implies that both students and teachers perceived that guidance and counseling services important. High-quality school counseling services can help to address students' mental health needs (U.S. Department of Education., 2002). It is believed that when school counselors have time, resources, and the better counseling room structure to work in, the counseling interventions programs improve students' academic achievement (Day., 2004).

For the question whether guidance and counseling improves student learning, both students and teachers were agreed as guidance and counseling services can improve students' learning. This was observed as the mean perceptions of students were $\mathrm{M}=4.01$ with $\mathrm{SD}=1.22$ ) and that of teachers were $(\mathrm{M}=4.17$ with $\mathrm{SD}=1.22)$. This was interpreted both students and teachers were agree as guidance and counseling is important to improve students' learning. The finding related with the views of American School Counselor Association, (1997) purpose of guidance and counseling service is to impart specific skills and learning opportunities in a proactive and preventive manner which ensures that all students can achieve school success through academic, career, and personal/ social development. Also according to Day, (2004) saying when school counselors have time, resources, and the better counseling room structure to work in, the counseling interventions programs improve students' academic achievement.

For the question whether non trained individual can give the survive of $\mathrm{G} \& \mathrm{C}$; the mean scores showed that the perception of the students toward the non trained individuals could be work as guidance and counselor officers were average while the teacher's perception were negative. The mean perception score of students was $(\mathrm{M}=2.99$ with $\mathrm{SD}=1.37)$ and the mean perception score of teachers was $(\mathrm{M}=2.065$ with $\mathrm{SD}=0.99$ ). The different perception mean scores of students and teachers may due to awareness and understanding difference of the issues. Wachira (1997) described that lack of training in guidance and 
counseling contributed to incompetence of the teacher-counselor hence unfavorable attitude towards the program. On other hand both students and teachers perception mean scores of guidance and counseling officers should be professionally trained was positive on the rating of students was $(\mathrm{M}=3.54$ with $\mathrm{SD}=$ 1.39) and that of teachers was $(\mathrm{M}=4.61$ with $\mathrm{SD}=0.72)$. This implies that both students and teachers perceived that guidance and counseling services officers should have professionally trained. Shertzer and Stone, (1981) support that, guidance and counseling services underscore the fact that other people opinions and decisions may have positive impact on the guidance and counseling services program. When the school guidance and counseling services are not provided for effectively, both teachers and students develop perceptions which may hinder their continued seeking for the same (Comfort., 2013).

Regarding to cost effectiveness of guidance and counseling services students perception mean score were negative which was $(\mathrm{M}=2.91$ with $\mathrm{SD}=1.38)$. Similarly the perception mean score of teachers toward cost effectiveness of guidance and counseling services were mean $(\mathrm{M}=3.25$ with $\mathrm{SD}=1.26)$. The mean scores of students and teachers were indicating that the cost effectiveness of their school guidance and counseling was below average. This finding was related with description of Ifelunni (2005) in secondary school setting there are problems related with non-professionalization of counselors, low counselor/ student ratio and lack of recognition from the school administrators toward guidance and counseling services. Also the words of Adane (2015), lack of commitment and creativity by professionals to promote the profession in the school is mentioned as the major challenge. According Paisley \& Hayes, (2003) for school counselors to become contributors to educational reform and enhance student success counselor training programs will require a transformation of both preparation and practice.

The mean scores of students and teachers toward guidance and counseling services given based on need assessment was $(\mathrm{M}=2.23$ with $\mathrm{SD}=1.37)$ for students and was $(\mathrm{M}=2.24$ with $\mathrm{SD}=1.1 .2)$ that of teachers respectively. The mean perception scores of both students and teachers were indicating that their schools guidance and counseling services were not working based on need assessments. For school counselors to become contributors to educational reform and enhance student success, counselor training programs will require a transformation of both preparation and practice (Paisley \& Hayes., 2003).

The mean perception scores of students and teachers toward guidance and counseling services given on students future career, personal problems and students empowerments and decision making was mean $(\mathrm{M}=2.26$ with $\mathrm{SD}=1.40)$ of students and that of teachers was $(\mathrm{M}=1.98$ with $\mathrm{SD}=1.40)$. Both teachers and students perception mean scores were negative. It implies interpreted that the guidance and counseling services of study area were less working on student's futures career, student personal problems, empowering students decision making. The current study was similar with Yirgalem Alemu (2013) Guidance \& Counseling services were poorly utilized by the school community of East Harerg zone. Oye, Obi and Mohd (2012) mentioned the essence of incorporating guidance and counseling into the school system was to eliminate overwhelming ignorance of many young people on their choices of career prospects and personality maladjustment. Similarly, (Lazarus and Chinwe., 2011: 57) reveled schools counselors assist learners in guiding decision-making and planned opportunities for students future career plan. Also according to Norman, Lela, and Marion (2011: 3) comprehensive guidance and counseling program addresses the needs of all students by facilitating their academic, career development, and personal/ social development, helping create positive and safe learning climates in schools, as well as helping students feel connected to school and to at least one caring adult. 


\section{Analysis of Independent T-Test of Students and Teachers Perception}

Table 4 Analysis of independent t-test of students and teachers perception

\begin{tabular}{llcccccccc}
\hline & & $\mathrm{N}$ & Mean & Std. D & $\mathrm{t}$ & $\mathrm{df}$ & Sg. & $\begin{array}{c}\text { Mean } \\
\text { Difference }\end{array}$ & $\begin{array}{c}\text { Sig. (2- } \\
\text { tailed) }\end{array}$ \\
\hline \multirow{2}{*}{ Stperception } & student data & 392 & & 5.464 & -2.625 & 498 & .092 & -1.51531 & .009 \\
& teacher data & 108 & 28.750 & 4.7145 & -2.854 & 193.61 & & -1.51531 & .005 \\
\hline
\end{tabular}

As Table 4 indicates $\mathrm{D}$, that the students mean perceptions guidance and counseling services scores were $27.234(\mathrm{SD}=5.464)$, where as the teachers mean perceptions guidance and counseling services scores to $28.750(\mathrm{SD}=4.714)$. The mean perception difference scores were -1.515. A 2-tailed ttest for spastically significant difference between the students and teachers scores significant at 0.05 level significance $(\mathrm{DF}=193, \mathrm{t}=0.092)$. The result revealed that there was no statistical significant difference between students and teachers means perception scores guidance and counseling services. This implies both teachers and students had the same perception for services of guidance and counseling in their schools.

\section{Conclusion}

The fact that both students and teachers respondents generally agreed that guidance and counseling services are necessary in their school, shows that there is direct need for these services in schools and the teachers acknowledge that they need the services. They view it as very necessary for the schools to implement the guiding and counseling services in secondary schools of south west Ethiopia. Also computed independent t-test of teachers and students perceptions show that they have positive perception for services of guidance and counseling in their schools. Though students and teachers perception towards the activities of $\mathrm{G} \& \mathrm{C}$ services is positive, the provisions of the services in those schools were limited or unavailable.

\section{Recommendation}

Based on the finding of this study, the following recommendations are forwarded:

Majorities of schools students and teachers have positive perception of guidance and counseling services needs for students learning. But, the perceptions of both students and teachers to ward school guidance and counseling working students future career, personal problems and students empowerments and decision making was negative. This implies that even if students and teachers believed guidance and counseling is important for students learning; the guidance and counseling centers were not effectively working according to students needs. So, most secondary schools of guidance and counseling programs were not working, the respective educational bureaus should work on the means of making the services accessible to all schools.

While perceptions of students and teachers may affected based on the guidance and counseling survives; Education bureau in collaboration with higher educational institutions should prepare on job training to improve counseling skills of the guidance and counselors officers. 


\section{Reference}

Adane, W. (2015). The Need, Practice and Challenges of Guidance and Counseling Services in Selected Sidama Zone Secondary Schools of SNNPRS Ethiopia: The International Journal of Humanities \& Social Studies (ISSN 2321 - 9203).

American School Counselor Association. (1997). The Role of the Professional School Counsellor. Alexandria,VA.

Beale, A. (2003). The Indispensible School Counselor. Principal Leadership, 4: 68-71.

Chireshe,G. (2011). School Counsellors' and Students' Perceptions of the Benefits of School Guidance and Counselling Services in Zimbabwean Secondary Schools: Kamla-Raj. J Soc Sci, 29(2): 101-108.

Cohen L, Manion L, Morrison K. (2001). Research Methods in Education. New York: RoutledgeFalmer.

Comfort, W. (2013). Evaluation of the Status of Guidance Services in Secondary Schools in Rivers State, Nigeria: Journal of Education and Practice www.iiste.org. ISSN 2222-1735 (Paper) ISSN 2222-288X (Online), 4(23).

David M, Sutton CD. (2004). Social Research: The Basics. London: Sage Publications.

Davies, S. M. B., Howes, A. J., \& Farrell, P. (2008). Tensions and Dilemmas as Drivers for the Change in an Analysis of Joint Working between Teachers and Educational Psychologists. School Psychology International, 29(4): 400-417. doi:10.1177/0143034308096439.

Day, S. X. (2004). Theory and Design in Counseling and Psychotherapy. Boston, NY: Houghton Mifflin Company.

Dean, R. S. (1980). A comparison of Preservice and Experienced Teachers' Perceptions of the School Psychologist. Journal of School Psychology, 18(3): 283-289.

Gilman, R., \& Gabriel, S. (2004). Perceptions of School Psychological Services by Education Professionals: Results from a Multi-State Survey Pilot Study. School Psychology Review, 33(2): 271286.

Gourneau, C. (2012). Bullying Cyber Bullying and Restorative Justice Practices. To Understand Students as a Whole and as Individuals.

Grace W. and Teresa A. (2015). School Guidance and Counseling in Kenya: Historical Development, Current Status, and Future Prospects: Journal of Education and Practice, 6(11).

Ifelunni I. (2005). The Missing Links in Nigerian Education System. Keynote Address Presented at a Conference on the State and Future of Education in Nigeria. F. C. E. (Technical) Asaba 13-17.

Lazarus, K. and Chinwe, I. (2011). The Role of Guidance Counsellors in the Career Development of Adolescents and Young Adults with Special Needs: British Journal of Arts and Social Sciences, 2(1). ISSN: 2046-9578.

Mundia, A. (1993). Modern Education Psychology for Teachers and Educationists. Machakos, Kenya: Triton Publishers. 
Mutie, E. K. \& Ndambuki. (1999). Guidance and Counselling for Schools and Colleges. Nairobi: Oxford.

Mutunga, J. M. (2003). Research on Effectiveness of Guidance and Counselling in Secondary Schools after the Ban of Corporal Punishment. (Unpublished Research Project). Egerton University, Nakuru, Kenya.

Mwangi, W. K. (2002). Student Perception of Guidance and Counselling: A Case Study of Loreto Schools, Nairobi. (Unpublished Master's Thesis). University of Nairobi, Nairobi, Kenya.

Oye N. D, Obi M. C, Mohd T. N. (2012). Guidance and Counseling in Nigerian Secondary Schools: The Role of ICT: I. J. Modern Education and Computer Science, (8): 26-33. DOI: 10.5815/ijmecs.2012.08. 04 .

Paisley, P. O., \& Hayes, R. L. (2003). School Counseling in the Academic Domain: Transformations in Preparation and Practice. Professional School Counseling, 6: 198-209.

Schacter. (2011). How to Help a Bully: Recommendations for Counseling the Proactive Aggressor. Professional School Counseling, 11: 120-128.

Shertzer, E. F. \& Stone, S. C. (1981). Fundamentals of Guidance. Boston: Houghton Mifflin Com.

U. S. Department of Education. (2002). No Child Left Behind: A desktop Reference. Washington, DC: Author.

UNESCO. (2011). Components of Guidance and Counseling Materials. www.freedocumentsearch.com /pdf/components-of-guidance-and.

Wachira J. N. (1997). Preparation of Secondary School Heads and Implications on their Performance. (Unpublished MED Thesis). Kenyatta University, Nairobi, Kenya.

Yamane, Taro. (1967). Statistics: An Introductory Analysis, 2nd Edition, New York: Harper and Row.

Yirgalem, A. (2013). Assessment of the Provisions of Guidance and Counseling Services in Secondary Schools of East Harerge Zone and Hareri Region, Ethiopia: Middle Eastern \& African Journal of Educational Research, (2): 28-37.

Yunis, A. H. (2006). Students' Attitudes and Perceptions of Guidance and Counselling Services in Secondary Schools in Kajiado Central Division, Kajiado District, Kenya: (Unpublished Mastes Thesis). Kenyatta University, Nairobi, Kenya.

\section{Copyrights}

Copyright for this article is retained by the author(s), with first publication rights granted to the journal.

This is an open-access article distributed under the terms and conditions of the Creative Commons Attribution license (http://creativecommons.org/licenses/by/4.0/). 